S.Afr. Tydskr. Landbouvoorl./S. Afr. J. Agric. Ext.,

Vol. 43, No. 2, 2015: $17-29$

DOI: http://dx.doi.org/10.17159/2413-3221/2015/v43n2a338
Shah, Grant

\& Stocklmayer

(Copyright)

\title{
FARMERS' PERCEPTION OF RISK IN CULTIVATING HYBRID RICE IN BANGLADESH
}

\author{
Shah, M. M. I. ${ }^{4}$, Grant, W. J. ${ }^{5}, \&$ Stocklmayer, S. ${ }^{6}$ \\ Correspondence Author: M M I Shah. Email: mmishah39@gmail.com
}

\begin{abstract}
Although there is an enormous potential for improving adoption of hybrid rice in Bangladesh, it is going through some difficulties in practice. Understanding farmers' perception about difficulties is critical to successful promotion. The present study was conducted to analyze farmers' perception of risk in cultivating hybrid rice and its relationship with the selected characteristics. The study was conducted in five regions of Bangladesh. A concurrent embedded design using a cross sectional survey was employed. The population of this study consisted of rice growers of the boro season. A multistage stratified random sampling design was employed in selecting the sample of 425 farmers. Data were collected through face-to-face interviews using a pre-tested and back translated questionnaire. Findings indicated that a vast majority of non-adopters (97.5\%), de-adopters (94.2\%) and continuing adopters (89.2\%) perceived moderate to serious risks in cultivating hybrid rice. Data also confirmed a significant relationship between farm size, promotional efforts, farmers' attitudes towards hybrid rice and their perception of risk in cultivating it. The results of this study raise important considerations for research leaders, policy makers and extension worker to refine the policy guidelines for the promotion of hybrid rice in Bangladesh.
\end{abstract}

Key words: risk, perception, survey, hybrid rice, farmer, Bangladesh

\section{BACKGROUND}

Even though Bangladesh has achieved significant progress in agriculture, especially with respect to rice production and yields, the demand for rice still outstrips domestic production, and the country remains a net importer of rice (FPMU 2008 as cited in (Ganesh-Kumar, Prasad, \& Pullabhotla, 2012)). There is a pressing need, however, to further improve rice production to meet the demands of the growing population, which increases at the rate of 1.32 percent per annum (BER, 2010) (as cited in Awal \& Siddique, 2011). Among the various options available to increase the rice yields, hybrid rice technology is the most feasible and readily adoptable as has been amply demonstrated in China (Nirmala \& Suhasini, 2013; Nirmala, Vasudev, \& Suhasini, 2013).

Hybrid rice could play an important role in food security, especially in poor countries in the tropics, where population is soaring and agricultural areas shrinking (Santiaguel \& Quipot, 2012). In particular, hybrid rice varieties have shown 15-20\% higher yield potential than

4 PhD Candidate, Australian National Centre for Public Awareness of Science, The Australian National University. Email: mmishah39@gmail.com

5 Lecturer and Graduate Studies Convenor, Australian National Centre for the Public Awareness of Science, Australian National University. Email: will.grant@anu.edu.au

6 Professor and Director, Australian National Centre for the Public Awareness of Science, The Australian National University. Email: sue.stocklmayer@anu.edu.au 
S.Afr. Tydskr. Landbouvoorl./S. Afr. J. Agric. Ext.,

Vol. 43, No. 2, 2015: $17-29$

DOI: http://dx.doi.org/10.17159/2413-3221/2015/v43n2a338
Shah, Grant

\& Stocklmayer

(Copyright)

inbred rice varieties and have demonstrated their ability to perform better under adverse conditions of drought and salinity (Singh et al., 2009). It is also reported that hybrid rice not only has a distinct yield advantage over inbred varieties (Chengappa, Janaiah, and Gowda, 2003) but also is more responsive to fertilizers and can adapt to varying environments. Above all, as the father of hybrid rice, Professor Longping Yuan (2012) has pointed out, Bangladesh can be self sufficient by cultivating hybrid rice. In the hope of achieving these outcomes, hybrid rice was introduced in the 1998-1999 boro season in Bangladesh, without a clear deployment strategy (Hossain, Janaiah, \& Husain, 2003) and its cultivation continues today.

The promotion of hybrid rice is, however, a challenging and time-consuming task (Cidro \& Radhakrishna, 2006), which has been reflected in the adoption process over the last decade in Bangladesh. By the 2008-09 crop year, only about 8\% of the rice area was planted with different rice hybrids (Janaiah \& Xie, 2010). On average, farmers brought $37.84 \%$ of their potential rice farming area for cultivation of hybrid rice over the period of 2001-2011 in the sample areas (Shah, Grant, \& Stocklmayer, 2014). They concluded that there is an enormous potential for improving the level of adoption of hybrid rice in Bangladesh. But in practice it is perceived to be unprofitable, risky, not easily integrated into existing farm practices.

The ultimate target for sustaining growth in rice production through hybrid rice is belied in practice. The field performance of this technology over a decade gives rise to a deep concern for the future of this technology. Therefore it is important to undertake a study analyzing the farmers' perceptions of risk in cultivating hybrid rice in Bangladesh. In order to guide the study, the following specific objectives were formulated: i) to assess farmers' perception of risk in cultivating hybrid rice ii) to develop an item-wise analysis of risk as perceived by farmers; iii) to explore the relationships between selected farmers' characteristics (age, educational qualification, family size, farm size, annual family income, training experience, organizational participation, communication exposure, promotional efforts, attitude towards hybrid rice and extent of adoption) and their attitude towards hybrid rice.

\section{RESEARCH METHOD \\ 2.1 Research site}

The land use pattern of Bangladesh is influenced by agro ecology, soil physiographic and climatic factors (BBS 2011). Based on these factors, the land in the country has been classified into 9 regions of which at least five have been gazetted by the Government of Bangladesh for on-farm evaluation of each variety of hybrid rice to be registered (GoB 2003). Therefore five regions were taken into account for this study in order to select the sample.

\subsection{Sampling design}

A concurrent embedded design using a cross sectional survey was employed (Creswell, 2009). The population of this study consisted of rice growers in the boro season who were responsible for farming decisions. A multistage stratified random sampling design as proposed by Babbie (1990) was employed in selecting the sample. In order to maintain the level of precision (sampling error) at $( \pm) 5 \%$, the level of confidence at $95 \%$ and the degree of variability at $50 \%, 425$ farmers were selected following sample size recommendations as proposed by Israel (2009); Dillman (2007); and Corbetta (2003). Farmers in three categories were sampled: namely, non-adopters (79), de-adopters (those who discontinue after having previously adopted-122) and continuing adopters (224) of hybrid rice. Data were collected through face-to-face interviews with the sampled farmers using a pre-tested and back 
S.Afr. Tydskr. Landbouvoorl./S. Afr. J. Agric. Ext.,

Vol. 43, No. 2, 2015: $17-29$

DOI: http://dx.doi.org/10.17159/2413-3221/2015/v43n2a338
Shah, Grant

\& Stocklmayer

(Copyright)

translated questionnaire. The questionnaire was formatted with both open and closed item questions to obtain both quantitative and qualitative data. The first author spent 120 working days in the study area between March 2 and June 30, 2012 to collect data.

\subsection{Measurement of risk as perceived by growers}

In order to quantity the perception of risk of the sampled farmers of hybrid rice cultivation, 16 risk items were identified from the areas of varietal selection, seed availability, susceptibility to drought and pest, physiological disorder like lodging, shattering and formation of empty grains, cost and care involvement, suitability of consumption, marketing status, yield stability, and proneness to damage of hybrid rice. The validity of the items was established using a panel of experts, which comprised the Graduate Committee Members, a hybrid rice scientist (working at Bangladesh Rice Research Institute) and an academician (Professor of Genetics and plant breeding at Banghbandhu Sheikh Mujibur Rahman Agricultural University (BSMRAU) and an Extension specialist working at DAE. This variable was measured by asking respondents to indicate their level of agreement in Likerttype scale as followed by Lucas \& Pabuayon, (2011) ranging from "none" to "a lot" weighted 0 to 3 , where 0 indicated 'no risk' and 3 indicated 'a lot' against individual item statement.

Average score for individual item statement with standard deviation was computed to find its relative position in the scale. To do so, the score for each point of the scale was calculated by multiplying its weighting with the number of responses. All weighted scores were then summed and then divided by the total number of responses to calculate the mean. Internal reliability of the scale used for measuring perception of risk was calculated using Cronbach's alpha, which was found to be 0.60. Henerson, Morris, \& Fitz-Gibbon (1987) stated that in the case of attitude measurement, a reliability coefficient of above 0.70 is desirable, but lower coefficients are also tolerated.

\subsection{Statistical analysis}

We reviewed each survey instrument for missing information (name of block, upazila and district), ineligible writing, and incomplete sentences and responses. Based on the outputs of the questionnaire survey, various statistical data analyses including analyses of frequencies, percentage, range of scores, means, and standard deviations of the variables were performed. In order to compare the groups of non-adopters, de-adopters and continuing adopters, Analysis of Variance (ANOVA) was performed.

\section{FINDINGS}

\subsection{Assessing farmers' perception of risk in cultivating hybrid rice}

The collective scores for the risk perception being rated by the non-adopters, de-adopters and continuing adopters ranged from 15-26, 13-28 and 9-28, with averages of 21.37, 22.0 and 20.21 and standard deviations of 2.89, 3.22, and 3.44, respectively. Based on the score for risk perception, each group of farmers is further categorized into three as shown in Table 1.

The computed $F$ value of 13.35 with 2 degrees of freedom at 0.001 level of probability shown in Table 1 means that there is a significant difference between non-adopters, de-adopters and continuing adopters in terms of risk they perceive in cultivating hybrid rice in their field or observing in adjoining fields of other farmers. 
S.Afr. Tydskr. Landbouvoorl./S. Afr. J. Agric. Ext.,

Vol. 43, No. 2, 2015: $17-29$

DOI: http://dx.doi.org/10.17159/2413-3221/2015/v43n2a338
Shah, Grant

\& Stocklmayer

(Copyright)

Table 1: Distribution of the respondents according to the perception of risk in cultivating hybrid rice.

\begin{tabular}{|c|c|c|c|c|}
\hline Category & $\begin{array}{c}\text { Non- } \\
\text { adopters }\end{array}$ & $\begin{array}{c}\text { De- } \\
\text { adopters }\end{array}$ & $\begin{array}{r}\text { Continuing } \\
\text { adopters }\end{array}$ & Total \\
\hline $\begin{array}{l}\text { Little risk } \\
(9-15)\end{array}$ & $\begin{array}{c}2 \\
(2.5)\end{array}$ & $\begin{array}{c}7 \\
(5.7) \\
\end{array}$ & $\begin{array}{c}22 \\
(9.8)\end{array}$ & $\begin{array}{c}31 \\
(7.3)\end{array}$ \\
\hline $\begin{array}{l}\text { Moderate risk } \\
(16-22)\end{array}$ & $\begin{array}{c}50 \\
(63.3) \\
\end{array}$ & $\begin{array}{c}58 \\
(47.5) \\
\end{array}$ & $\begin{array}{c}141 \\
(63.0)\end{array}$ & $\begin{array}{c}249 \\
(58.6) \\
\end{array}$ \\
\hline $\begin{array}{l}\text { Serious risk } \\
(23-29)\end{array}$ & $\begin{array}{c}27 \\
(34.2)\end{array}$ & $\begin{array}{c}57 \\
(46.7)\end{array}$ & $\begin{array}{c}61 \\
(27.2)\end{array}$ & $\begin{array}{c}145 \\
(34.1)\end{array}$ \\
\hline Total & $\begin{array}{c}79 \\
(100)\end{array}$ & $\begin{array}{c}122 \\
(100)\end{array}$ & $\begin{array}{c}224 \\
(100)\end{array}$ & $\begin{array}{c}425 \\
(100)\end{array}$ \\
\hline \multicolumn{5}{|c|}{ Computed statistics } \\
\hline Minimum & 15 & 13 & 9 & 9 \\
\hline Maximum & 26 & 28 & 28 & 28 \\
\hline Mean & 21.37 & 22.0 & 20.21 & 20.94 \\
\hline SD & 2.89 & 3.22 & 3.44 & 3.37 \\
\hline F statistics & $12.33 * * *$ & & & \\
\hline
\end{tabular}

Figure in parentheses indicate percentage; ${ }^{* * *}$ indicates significant at $0.1 \%$ level

As a whole, however, a vast majority of non-adopters (97.5\%), de-adopters $(94.2 \%)$ and continuing adopters $(89.2 \%)$ perceived moderate to serious risk for cultivating hybrid rice. The findings suggest that non-adopters are more anxious about the risk than de-adopters and continuing adopters, which keeps them away from initiating cultivation of hybrid rice. At the same time farmers from all three groups are vulnerable to risk. Continuing adopters still continue cultivating hybrid rice because of possessing larger farms and having higher family incomes. Janaiah, Hossain, \& Husain (2002) conducted a study on hybrid rice in India and Bangladesh and reported that higher risk in cultivating hybrid rice is one of key issues for farmers (as indicated by about $80 \%$ of respondents). But the actual risk occurrence is not ubiquitous; rather it is area specific.

\subsection{An item-wise analysis of risk as perceived by farmers}

Findings focused on perceived risk against individual question-item are analyzed. The first six risk items are listed in Table 2. The next risk items from 7 to 12 are presented in Table 3 . Finally the last five risk items are given in Table 4 
S.Afr. Tydskr. Landbouvoorl./S. Afr. J. Agric. Ext.,

Vol. 43, No. 2, 2015: $17-29$

DOI: http://dx.doi.org/10.17159/2413-3221/2015/v43n2a338
Shah, Grant

\& Stocklmayer

(Copyright)

Table 2: Analysis of risk items ( 1 to 6$)$ as perceived by non-adopters $(\mathrm{N}=79)$, de-adopters $(\mathrm{N}=122)$ and continuing adopters $(\mathrm{N}=224)$

\begin{tabular}{|c|c|c|c|c|c|}
\hline \multirow[t]{2}{*}{ Category } & \multicolumn{3}{|c|}{ Extent of risk } & \multicolumn{2}{|c|}{ Sample statistic } \\
\hline & No risk & A little risk & A lot risk & Mean & SD \\
\hline Risk 1 & \multicolumn{5}{|c|}{ Is selecting the right variety of hybrid rice difficult? } \\
\hline Non-adopters & $5(6.3)$ & $4(5.1)$ & $70(88.6)$ & 1.82 & 0.53 \\
\hline De-adopters & $11(9.0)$ & $5(4.1)$ & $106(86.9)$ & 1.78 & 0.60 \\
\hline Continuing adopters & $43(19.2)$ & $3(1.3)$ & $178(79.5)$ & 1.60 & 0.80 \\
\hline Total & $59(13.9)$ & $12(2.8)$ & $354(83.3)$ & 1.69 & 0.70 \\
\hline Risk 2 & \multicolumn{5}{|c|}{$\begin{array}{c}\text { Are hybrid rice seeds scarcer in market than HYVs during planting } \\
\text { time? }\end{array}$} \\
\hline Non-adopters & $76(96.2)$ & $1(1.3)$ & $2(2.5)$ & 0.06 & 0.11 \\
\hline De-adopters & $115(94.3)$ & $4(3.3)$ & $3(2.5)$ & 0.08 & 0.35 \\
\hline Continuing adopters & $216(96.4)$ & $7(1.6)$ & $1(0.4)$ & 0.04 & 0.22 \\
\hline Total & $407(95.8)$ & $12(2.8)$ & $6(1.4)$ & 0.06 & 0.29 \\
\hline Risk 3 & \multicolumn{5}{|c|}{$\begin{array}{l}\text { Is hybrid rice more susceptible to drought than conventional } \\
\text { inbreeds? }\end{array}$} \\
\hline Non-adopters & $4(5.1)$ & $7(8.9)$ & $68(86.0)$ & 1.84 & 0.54 \\
\hline De-adopters & $0(0.0)$ & $12(9.8)$ & $110(90.2)$ & 1.90 & 0.30 \\
\hline Continuing adopters & $6(2.7)$ & $38(17.0)$ & $180(80.4)$ & 1.78 & 0.48 \\
\hline Total & $10(2.4)$ & $57(13.4)$ & $358(84.2)$ & 1.82 & 0.45 \\
\hline Risk 4 & \multicolumn{5}{|c|}{ Is lodging more likely to appear in hybrid rice than HYVs? } \\
\hline Non-adopters & $76(96.2)$ & $3(3.8)$ & $0(0.0)$ & 0.08 & 0.39 \\
\hline De-adopters & 118 (96.7) & $4(3.3)$ & $0(0.0)$ & 0.03 & 0.18 \\
\hline Continuing adopters & $218(97.3)$ & $5(2.2)$ & $1(0.4)$ & 0.03 & 0.20 \\
\hline Total & $412(96.9)$ & $12(2.8)$ & $1(0.2)$ & 0.04 & 0.24 \\
\hline Risk 5 & \multicolumn{5}{|c|}{$\begin{array}{l}\text { Are hybrid rice grains more likely to shatter from panicles than othe } \\
\text { HYVs? }\end{array}$} \\
\hline Non-adopters & $63(79.7)$ & $14(17.7)$ & $2(2.5)$ & 0.23 & 0.48 \\
\hline De-adopters & $64(52.5)$ & $40(32.8)$ & $18(14.8)$ & 0.62 & 0.73 \\
\hline Continuing adopters & $144(64.3)$ & $71(31.7)$ & $9(4.0)$ & 0.40 & 0.57 \\
\hline Total & $271(63.8)$ & $125(29.4)$ & $29(6.8)$ & 0.43 & 0.62 \\
\hline Risk 6 & \multicolumn{5}{|c|}{$\begin{array}{l}\text { Are hybrid grains, more likely to be converted into empty grains than } \\
\text { inbreed? }\end{array}$} \\
\hline Non-adopters & $23(29.1)$ & $44(55.7)$ & $12(15.2)$ & 0.89 & 0.70 \\
\hline De-adopters & $37(30.3)$ & $63(51.6)$ & $22(18.0)$ & 0.88 & 0.69 \\
\hline Continuing adopters & $93(41.5)$ & $119(53.1)$ & $12(5.4)$ & 0.64 & 0.58 \\
\hline Total & $153(36.0)$ & $226(53.2)$ & $46(10.8)$ & 0.75 & 0.65 \\
\hline
\end{tabular}

Risk 1: Is selecting the right variety of hybrid rice difficult? In order to clarify the meaning of the question (if respondent failed to understand), the researcher often asked a supplementary question like "is the pure seed of a specific variety of hybrid rice difficult". A great majority of non-adopters (88.6\%), de-adopters (86.9\%) and continuing adopters $(79.5 \%)$ showed deep concern about varietal selection. Usually farmers practice two approaches to variety selection: farmers first try to identify the best variety that has been performing in their locality, and then learn the name of that particular variety from the owner and go to the dealer to purchase it. Second, a farmer may go to the dealer outright and ask for a good variety to be cultivated in his field. In this case, farmers are mostly deceived. One of the sampled farmers from Bouglagari Block under Kishoreganj upazila of Nilphamari reported "I decided to cultivate Jhalak, as the variety produces fine rice and has a good taste for consumption. Accordingly I bought a packet of seed labeled as Jhalak and cultivated it. But after harvesting, I found that it was not Jhalak. That greatly disappointed me". Another quote 
S.Afr. Tydskr. Landbouvoorl./S. Afr. J. Agric. Ext.,

Vol. 43, No. 2, 2015: $17-29$

DOI: http://dx.doi.org/10.17159/2413-3221/2015/v43n2a338

regarding deception on buying good seed was "farmers are usually cheated on buying seeds" (de-adopters).

In order to cultivate hybrid rice, the National Seed Board (NSB) of Bangladesh approved 73 varieties through gazette notification (GoB, 2003). Unfortunately no rigorous performance evaluation trial has yet been started by the Government of Bangladesh, as mentioned by one of the scientists working in the Bangladesh Rice Research Institute (BRRI) while conversing with the first author on May 1, 2012. The NSB also does not monitor and supervise the performance of imported seed at farmers' fields. Exploiting this opportunity, private seed companies have imported more than 50 rice hybrids largely from China and India (Janaiah et al., 2002) to be sold to farmers at exorbitant prices for profit. Additionally farmers claimed that the outstanding amounts of imported seeds that are not sold in the current season are unscrupulously preserved for selling in the following season ignoring the deterioration of germination percentage and its consequential impact.

Risk 2: Are hybrid rice seeds scarcer in market than High Yielding Varieties (HYVs) during planting time? In response to the question item a great majority of non-adopters $(96.2 \%)$, deadopters $(96.4 \%)$ and continuing adopters $(95.8 \%)$ put their opinion against the question. They stated that seeds of hybrid rice are available in the market but they are not sure about the quality of the seeds (whether these seeds are pure or faulty).

Risk 3: Is hybrid rice more susceptible to drought than conventional inbreeds? In response to the question, a great majority of non-adopters $(86.0 \%)$, de-adopters $(90.2 \%)$ and continuing adopters $(80.4 \%)$ considered hybrid rice more susceptible to drought.

Risk 4: Is lodging more likely to appear in hybrid rice than HYVs? The vast majority of nonadopters (96.2\%), de-adopters (96.7\%) and continuing adopters (97.3\%) stated that hybrid rice is no more prone to lodging. Rather, it is resistant to lodging. This is one of the best qualities of hybrid rice, which farmers particularly appreciate when cultivating in low land.

Risk 5: Are hybrid rice grains more likely to shatter from panicles than other HYVs? Regarding this question, a majority of non-adopters $(79.7 \%)$, de-adopters $(52.5 \%)$ and continuing adopters $(64.3 \%)$ responded that shattering is no longer observed as a problem in hybrid rice cultivation.

Risk 6: Are hybrid grains more likely to be converted into empty grains than inbreed? What was found in response to this question is that a majority of non-adopters (55.7\%), de-adopters $(51.6 \%)$ and continuing adopters $(53.1 \%)$ reported that formation of empty grain is little. It appears that formation of empty grains is highly correlated with existing climatic conditions. It is reported by BRRI (2011) that fluctuation of temperature at the flowering stage leads to the formation of unfilled grains. If the temperature goes below $12-13^{\circ} \mathrm{C}$ at night and above $28-29^{0} \mathrm{C}$ during the day, it is considered critical to forming unfilled grains. Such a precarious situation occurring for 5-6 days turns into a catastrophe in the rice field. 
S.Afr. Tydskr. Landbouvoorl./S. Afr. J. Agric. Ext.,

Vol. 43, No. 2, 2015: $17-29$

DOI: http://dx.doi.org/10.17159/2413-3221/2015/v43n2a338
Shah, Grant

\& Stocklmayer

(Copyright)

Table 3: Analysis of risk items ( 7 to 12$)$ as perceived by non-adopters ( $N=79)$, de-adopters $(\mathrm{N}=122)$ and continuing adopters $(\mathrm{N}=224)$

\begin{tabular}{|c|c|c|c|c|c|}
\hline \multirow[t]{2}{*}{ Category } & \multicolumn{3}{|c|}{ Extent of risk } & \multicolumn{2}{|c|}{ Sample statistic } \\
\hline & No risk & A little risk & A lot risk & Mean & SD \\
\hline Risk 7 & \multicolumn{5}{|c|}{ Is hybrid rice more susceptible to disease than HYVs? } \\
\hline Non-adopters & $2(2.5)$ & $29(36.7)$ & $48(60.8)$ & 1.58 & 0.55 \\
\hline De-adopters & $1(0.8)$ & $32(26.2)$ & $89(73.0)$ & 1.72 & 0.47 \\
\hline Continuing adopters & $8(3.6)$ & $86(38.4)$ & $130(58.0)$ & 1.54 & 0.57 \\
\hline Total & $11(2.6)$ & $147(34.6)$ & $267(62.8)$ & 1.60 & 0.54 \\
\hline Risk 8 & \multicolumn{5}{|c|}{ Is hybrid rice more susceptible to insect pest than HYVs? } \\
\hline Non-adopters & $0(0.0)$ & $18(22.8)$ & $61(77.2)$ & 1.77 & 0.42 \\
\hline De-adopters & $1(0.8)$ & $21(17.2)$ & $100(82.0)$ & 1.81 & 0.41 \\
\hline Continuing adopters & $2(0.9)$ & $56(25.0)$ & $166(74.1)$ & 1.73 & 0.47 \\
\hline Total & $3(0.7)$ & $95(22.4)$ & $327(76.9)$ & 1.76 & 0.44 \\
\hline Risk 9 & \multicolumn{5}{|c|}{ Does hybrid rice require more intensive care than HYVs? } \\
\hline Non-adopters & $0(0.0)$ & $5(6.3)$ & $74(93.7)$ & 1.94 & 0.25 \\
\hline De-adopters & $4(3.3)$ & $5(4.1)$ & $113(92.6)$ & 1.89 & 0.40 \\
\hline Continuing adopters & $6(2.7)$ & $18(8.0)$ & $200(89.3)$ & 1.87 & 0.41 \\
\hline Total & $10(2.4)$ & $28(6.6)$ & $387(91.1)$ & 1.89 & 0.38 \\
\hline Risk 10 & \multicolumn{5}{|c|}{ Is hybrid rice more cost intensive than HYVs? } \\
\hline Non-adopters & $0(0.0)$ & $1(1.3)$ & $78(98.7)$ & 1.99 & 0.11 \\
\hline De-adopters & $1(0.8)$ & $5(4.1)$ & $116(95.1)$ & 1.94 & 0.28 \\
\hline Continuing adopters & $0(0.0)$ & $12(5.4)$ & $212(94.6)$ & 1.95 & 0.22 \\
\hline Total & $1(0.2)$ & $18(4.2)$ & $406(95.5)$ & 1.95 & 0.22 \\
\hline Risk 11 & \multicolumn{5}{|c|}{ Do people avoid consuming hybrid rice? } \\
\hline Non-adopters & $0(0.0)$ & $1(1.3)$ & $78(98.7)$ & 1.99 & 0.11 \\
\hline De-adopters & $2(1.6)$ & $1(0.8)$ & $119(97.5)$ & 1.96 & 0.27 \\
\hline Continuing adopters & $6(2.7)$ & $10(4.5)$ & $208(92.9)$ & 1.90 & 0.38 \\
\hline Total & $8(1.9)$ & $12(2.8)$ & $405(95.3)$ & 1.93 & 0.32 \\
\hline Risk 12 & \multicolumn{5}{|c|}{ Is the selling price of hybrid rice lower than inbred varieties? } \\
\hline Non-adopters & $0(0.0)$ & $1(1.3)$ & $78(98.7)$ & 1.99 & 0.11 \\
\hline Discontinuers & $1(0.8)$ & $4(3.3)$ & $117(95.9)$ & 1.95 & 0.25 \\
\hline Continuing adopters & $5(2.2)$ & $6(2.7)$ & $213(95.1)$ & 1.93 & 0.33 \\
\hline Total & $6(1.4)$ & $11(2.6)$ & $408(96.0)$ & 1.95 & 0.28 \\
\hline
\end{tabular}

Risk 7: Is hybrid rice more susceptible to disease than HYVs? The majority of non-adopters $(60.8 \%)$, de-adopters $(73.0 \%)$ and continuing adopters $(58.0 \%)$ stated that this is a problem farmers faced a lot.

Risk 8: Is hybrid rice more susceptible to insect pest than HYVs? This is one of the alarming concerns farmers faced a lot, as stated by $77.2 \%$ of non-adopters, $82.0 \%$ of de-adopters and $74.1 \%$ of continuing adopters. After 20-25 days of transplanting, the plants turn soft and succulent through natural growth. In addition, farmers usually apply imbalanced fertilizers because of ignorance and cause undesired vegetative growth producing tender leaves and stems, which are susceptible to disease attack and insect infestation. Hence they should always be watchful for preventing this occurrence.

Risk 9: Does hybrid rice require more intensive care than HYVs? More than $90 \%$ of farmers from all three categories are convinced that hybrid rice requires a lot more intensive care than HYVs. Farmers also claimed that delays in performing crop management practices such as 
S.Afr. Tydskr. Landbouvoorl./S. Afr. J. Agric. Ext.,

Vol. 43, No. 2, 2015: $17-29$

DOI: http://dx.doi.org/10.17159/2413-3221/2015/v43n2a338
Shah, Grant

\& Stocklmayer

(Copyright)

the application of pesticides, fertilizers and irrigation leads to a reduction of yield. Thus farmers keep a wary eye on the requirements of crops and take immediate action.

Risk 10: Is hybrid rice more cost intensive than HYVs? With respect to this question, about $95 \%$ of farmers from all three categories clearly indicated that cultivation of hybrid rice is a lot more cost intensive than conventional inbreds.

Risk 11: Do people avoid consuming hybrid rice? An overwhelming majority of all three categories noted that people avoided consuming hybrid rice because of its unsuitability for consumption. This is one of the vital issues that largely discourage farmers, especially those who are subsistent and semi-subsistent.

Risk 12: Is the selling price of hybrid rice lower than inbred varieties? Regarding this question more than $95 \%$ of all respondents are seriously concerned. Offsetting the production cost at the current price is a big challenge for them. The current market price of hybrid rice is lower than inbred varieties by 150-250 BDT (USD1.9- USD 3.2, USD I $=77.8$ BDT as of August 18, 2015, Bangladesh Bank) for $37.5 \mathrm{~kg}$ depending on the grain size. It is one of most crucial factors that largely influence farmers, causing rejection.

Table 4: Analysis of risk items ( 1 to 6$)$ as perceived by non-adopters $(\mathrm{N}=79)$, de-adopters $(\mathrm{N}=122)$ and continuing adopters $(\mathrm{N}=224)$

\begin{tabular}{l|l|l|l|l|l|}
\hline \multirow{2}{*}{ Category } & \multicolumn{4}{|c|}{ Extent of risk } & \multicolumn{2}{c}{ Sample statistic } \\
\cline { 2 - 7 } & No risk & A little risk & A lot risk & Mean & SD \\
\hline Risk 13 & \multicolumn{1}{|c|}{ Is farmer struggling with lower market demand of hybrid rice? } \\
\hline Non-adopters & $7(8.9)$ & $9(11.4)$ & $63(79.7)$ & 1.71 & 0.62 \\
\hline De-adopters & $13(10.7)$ & $18(14.8)$ & $91(74.6)$ & 1.64 & 0.67 \\
\hline Continuing adopters & $41(18.3)$ & $41(18.3)$ & $142(63.4)$ & 1.46 & 0.80 \\
\hline Total & $61(14.4)$ & $68(16.0)$ & $296(69.6)$ & 1.56 & 0.73 \\
\hline Risk 14 & \multicolumn{5}{|c}{ Does the yield of hybrid rice fluctuate? } \\
\hline Non-adopters & $8(10.1)$ & $52(65.8)$ & $19(24.1)$ & 1.16 & 0.61 \\
\hline De-adopters & $10(8.2)$ & $77(63.1)$ & $35(28.7)$ & 1.25 & 0.64 \\
\hline Continuing adopters & $25(11.2)$ & $139(62.0)$ & $60(26.8)$ & 1.17 & 0.62 \\
\hline Total & $43(10.1)$ & $268(63.1)$ & $114(26.8)$ & 1.20 & 0.62 \\
\hline Risk 15 & \multicolumn{5}{|c|}{ Did any damage of hybrid rice occur in field? } \\
\hline Non-adopters & $43(54.4)$ & $4(5.1)$ & $32(40.5)$ & 0.86 & 0.97 \\
\hline De-adopters & $59(48.4)$ & $14(11.5)$ & $49(40.2)$ & 0.92 & 0.94 \\
\hline Continuing adopters & $106(47.3)$ & $22(9.8)$ & $96(42.9)$ & 0.96 & 0.95 \\
\hline Total & $208(48.9)$ & $40(9.4)$ & $177(41.6)$ & 0.93 & 0.95 \\
\hline Risk 16 & Do you fear any crop damage by natural calamities for the upcoming \\
\hline \multicolumn{7}{|l|}{ seasons? } \\
\hline Non-adopters & $18(22.8)$ & $7(8.9)$ & $54(68.3)$ & 1.47 & 0.86 \\
\hline De-adopters & $19(15.6)$ & $9(7.4)$ & $94(77.0)$ & 1.61 & 0.74 \\
\hline Continuing adopters & $60(26.8)$ & $54(24.1)$ & $110(49.1)$ & 1.22 & 0.84 \\
\hline Total & $97(22.8)$ & $70(16.5)$ & $258(60.7)$ & 1.38 & 0.84 \\
\hline
\end{tabular}

Risk 13: Is the farmer struggling with lower market demand for hybrid rice? The majority of non-adopters $(79.7 \%)$, de-adopters $(74.6 \%)$ and continuing adopters $(63.4 \%)$ have suffered a lot from lower market demand. Private buyers do not want to buy hybrid rice. In consequence, growers have to wait for Government dealers. Even then, there is a problem they have to struggle with because Government dealers are not usually interested in purchasing less than $2000 \mathrm{~kg}$ rough rice (equivalent to produce at least $1000 \mathrm{~kg}$ husked rice). 
S.Afr. Tydskr. Landbouvoorl./S. Afr. J. Agric. Ext.,

Vol. 43, No. 2, 2015: $17-29$

DOI: http://dx.doi.org/10.17159/2413-3221/2015/v43n2a338

The majority farmers do not harvest that much. As per the DAE field report (2011) the average size of operational holdings (actual area cultivated) for rice is only 0.034 hectares and the average production of husked hybrid (chaul in Bengali) rice in the 2010-2011 boro season was $4.675 \mathrm{t} / \mathrm{ha}$. A farmer thus expected to produce $0.1589 \mathrm{t} / \mathrm{ha}$ on average which is equivalent to $158.95 \mathrm{~kg}$ husked rice which is still far behind the expected demand of the Government millers.

Risk 14: Does the yield of hybrid rice fluctuate? The majority of non-adopters (65.8\%), deadopters $(63.1 \%)$ and continuing adopters $(62.0 \%)$ rated this question as a problem with little impact. One farmer opined that "production is not stable, it varies. Some farmers get higher yields but some do not and unfortunately some go through loss". The fluctuation is sometimes caused by natural disasters, like the formation of unfilled grains, a shattering by hailstorms, which fluctuate severely and creates havoc. However, the variation is slight and natural. The same also happens to inbreds. Farmers also reported that minor fluctuations in yield may be caused by repeated cultivation of the same variety in the same piece of land.

Risk 15: Did any damage of hybrid rice occur in the field? The majority of non-adopters (54.4\%) did not notice any crop damage in their neighbour's field, but the majority of deadopters $(51.7 \%)$ experienced crop damage in their field at least once in the tenure of hybrid rice cultivation. So also did the majority of continuing adopters (51.0\%).

Risk 16: Do you fear any crop damage by natural calamities for the upcoming seasons? The majority of non-adopters $(68.3 \%)$ and de-adopters $(77.0 \%)$ disclosed that they remain greatly suspicious about crop damage by impending disasters. They had to spend the tenure of the crop season, particularly during the harvesting season, with a lot more fear and anxiety for crop loss particularly by hailstorms and flash floods. The case of continuing adopters, however, is somewhat resistant. About $49 \%$ of them fear crop damage a lot while $24.1 \%$ fear a little. In response to the question one farmer became totally upset and emotional, stating that "by sighting the formation of dark clouds in the sky we fear of hailstorm: if it starts it will cause a disaster through much shattering of grain". In addition, a dealer also reported that "he is informed by a farmer from Habganj district that he harvested 5 mounds from 30 decimal land after his field had a hailstorm where he was supposed to harvest at least 25 mound instead."

\subsection{Relationships between farmers' characteristics and their attitude towards hybrid rice}

Studies have shown that farmers' personal characteristics have some influence on their perception of innovations and their decision to adopt or reject such innovations (Jegede, Bolorunduro, \& Ikani, 2007). In this study the data showed a significant positive relationship (Table 5) between farm size, promotional efforts and farmers' perception of risk in cultivating hybrid rice while there was a significant negative relationship between attitudes of farmers and their perception of risk in cultivating hybrid rice. 
S.Afr. Tydskr. Landbouvoorl./S. Afr. J. Agric. Ext.,

Vol. 43, No. 2, 2015: $17-29$

DOI: http://dx.doi.org/10.17159/2413-3221/2015/v43n2a338
Shah, Grant

\& Stocklmayer

(Copyright)

Table 5: Co-efficient of Correlation (r) Between the Dependent Variables of Farmers' Perception of Risk in Cultivating Hybrid rice and Independent Variables

\begin{tabular}{lll}
\hline Dependent variable & Independent variable & 'r' value \\
\hline Perception of risk in & Age & $-0.05^{\text {NS }}$ \\
cultivating hybrid rice & Educational qualification & $0.05^{\text {NS }}$ \\
& Family size & $-0.08^{\text {NS }}$ \\
& Farm size & $0.14^{* *}$ \\
& Annual family income & $-0.02^{\text {NS }}$ \\
& Training experience & $-0.01^{\text {NS }}$ \\
& Organizational participation & $0.05^{\text {NS }}$ \\
& Communication exposure & $-0.04^{\text {NS }}$ \\
& Promotional efforts & $0.17^{* * *}$ \\
& Attitude towards hybrid rice & $-0.46^{* * *}$ \\
& Extent of adoption & $0.03^{\text {NS }}$ \\
\hline
\end{tabular}

${ }^{\mathrm{NS}}$ Non significant; $*, * *, * * *$ Significant at $0.05,0.01,0.001$, respectively

The above statement can be interpreted as indicating that owning a larger farm creates scope for more cultivation that then increases the chance of being affected by unavailability of pure seeds, varietal choice, drought, lodging, shattering, empty grains, diseases and insect pests, intensive care and cost, consumption difficulties, lower market prices, yield fluctuation and natural calamities. The bigger farm thus increases the risk in cultivating hybrid rice. Farmers are motivated by the promotional assistance offered and start cultivating the hybrid: with the intensification of their cultivation they then become more exposed to the associated risk. On the other hand, favourable attitudes of the farmers towards hybrid rice cultivation inspire them to be cautious and careful about cultivation procedures and to seek ways to avoid impending natural calamities. However, age, educational qualification, family size, annual family income, training experience, organizational participation, communication exposure, and extent of adoption had no significant relationship on risk perception.

\section{CONCLUSIONS}

A significant difference was found between de-adopters and continuing adopters in terms of risk as perceived by them. A vast majority of non-adopters (97.5\%), de-adopters (94.2\%) and continuing adopters $(89.2 \%)$ perceived moderate to serious risk in cultivating hybrid rice. The findings indicated that non-adopters are more anxious about the risk than de-adopters and continuing adopters, which probably keeps them away from initiating cultivation of hybrid rice. The major risk items were: selecting the right variety; susceptibility of the plants to drought, insect pest and disease, requiring intensive crop care and greater cost; lower consumer demand and market price; year-wise yield fluctuation; and a continuous obsession about impending disaster. The data also showed a significant positive relationship between farm size, promotional efforts and perception of risk in cultivating hybrid rice but a significant negative relationship between farmers' attitudes towards hybrid rice and their perception of risk in cultivating it.

\section{POLICY IMPLICATIONS}

The results of this study raise important considerations for researchers, administrators, policy makers and extension workers. A number of opportunities exist to refine working procedures and policy guidelines in the areas of discovery, development and delivery of hybrid rice, as 
S.Afr. Tydskr. Landbouvoorl./S. Afr. J. Agric. Ext.,

Vol. 43, No. 2, 2015: $17-29$

DOI: http://dx.doi.org/10.17159/2413-3221/2015/v43n2a338

presented below:

1. Varietal selection has tremendous impact on the yield performance of hybrid rice. In order to approve variety seed certification agency (SCA), the Government of Bangladesh should apply a stringent monitoring and evaluation process. The grassroots level workers of the sister extension organizations should guide farmers in selecting the right variety.

2. Importing quality seed and supplying to the farmers in due course is one of the key issues for prompting hybrid rice cultivation. Unfortunately, selling outdated seeds is an open secret and has already been established as a regular practice. Victims are numerous and seriously suffer. The authority in this regard should attempt to identify the unscrupulous seed dealers and bring them under the jurisdiction of law. If the problem goes officially unidentified, the future of this technology would be highly questionable.

3. Offering required complementary inputs and irrigation equipment at subsidized rates would be helpful. Action to ratify rationalized and regulated market prices is an urgent issue to be addressed. Furthermore, the Government of Bangladesh should purchase raw hybrid rice in the season, at reasonable prices, to help farmers to get their product sold and to encourage them to continue cultivating hybrid rice.

4. Establishing seed industries might help develop domestic seed that might be well adapted to the land and environment of the country. Increased domestic seed supply can help not only overcome seed quality problems but also ensure availability of the seed early in the season. This may also create employment opportunities for the unemployed rural youth.

5. As hybrid rice is coarse, this alienates farmers from its consumption. Future research should be directed towards developing finer rice producing varieties. The dictum that "Bangladeshis are habituated to take coarse rice and thick cloths" gets disproved more and more these days. Substantial changes in terms of taste and preference of Bangladeshis have taken place over time. Today, people prefer fine rice for their daily consumption.

6. A regular monitoring and supervision of grass-roots level extension workers in the crop field is crucial to guide farmers in following the recommended procedure and making them aware of potential hazards in the crop fields.

\section{ACKNOWLEDGEMENTS}

We are grateful to DAE and the farmers who participated in this study. Also, thanks to Department of Education, Employment and Workplace Relations (Australian Federal Government) for providing a doctoral scholarship and the International Crops Research Institute for the Semi-Arid Tropics (ICRISAT) for offering a research grant to conduct fieldwork to the first author of this paper.

\section{REFERENCES}

AWAL, M. A., \& SIDDIQUE, M. A. B. 2011. Rice Production In Bangladesh Employing By Arima Model. Bangladesh Journal of Agricultural Research, 36(1), 51-62.

BABBIE, E. 1990. Survey research methods (2nd ed.). Belmont, CA: Wadsworth.

BBS. 2011. Yearbook of Agricultural Statistics of Bangladesh.

BRRI. 2011. Adhunik Dhaner Chas (p. 61). Gazipur: Bangladesh Rice Research Institute. 
S.Afr. Tydskr. Landbouvoorl./S. Afr. J. Agric. Ext.,

Vol. 43, No. 2, 2015: $17-29$

DOI: http://dx.doi.org/10.17159/2413-3221/2015/v43n2a338
Shah, Grant

\& Stocklmayer

(Copyright)

CHENGAPPA, P. G., JANAIAH, A. \& GOWDA, M. V. S. 2003. Profitability of Hybrid Rice Cultivation: Evidence from Karnataka. Economic and Political Weekly, 38(25), 2531-2534.

CIDRO, D. A. \& RADHAKRISHNA, R. B. 2006. Farmers' and Extension Agents' Perceptions of the Philippines Hybrid Rice Program. Journal of International Agriculture and Extension Education, 13(3), 19-32.

CORBETTA, P. 2003. Social Research: Theory, Methods and Techniques. London: Sage.

CRESWELL, J. W. 2009. Research Design: Qualitative, Quantitative, and Mixed Methods Approaches (3rd ed., p. 5). Thousand Oaks, CA: Sage.

DAE. 2011. A report on cultivation and production of rice for the 2010-2011 boro season, Department of Agricultural Extension, Khamarbari, Dhaka (Translated from Bengali).

DILLMAN, D. A. 2007. Reduction of Coverage and Sampling Error. In Mail and Internet Surveys: The Tailored Design Method (2nd edn.). Hoboken, New Jersey: John Wiley \& Sons, Inc.

GANESH-KUMAR, A., PRASAD, S. K. \& PULLABHOTLA, H. 2012. Supply and Demand for Cereals in Bangladesh, 2010-2030 (No. IFPRI Discussion Paper 01186). New Delhi.

GOB. (2003). Bangladesh Gazette, p. 64. Bangladesh: Bangladesh Gazzette.

GUERIN, L. \& GUERIN, T. 1994. Constraints to the adoption of innovations in agricultural research and environmental management: a review. Australian Journal of Experimental Agriculture, 34(4), 549-571. doi:10.1071/EA9940549

HENERSON, M. E., MORRIS, L. L. \& FITZ-GIBBON, C. T. 1987. How to measure attitudes. Newbury Park, CA: Sage.

HOSSAIN, M., JANAIAH, A. \& HUSAIN, M. 2003. Hybrid rice in Bangladesh: Farm-level performance. Economic and Political Weekly, 38(25), 2517-2522.

ISRAEL, G. 2009, April. Determining Sample Size. \#PEOD6, 1-5.

JANAIAH, A., HOSSAIN, M. \& HUSAIN, M. 2002. Hybrid rice for tomorrow's food security: can the chinese miracle be replicated in other countries? Outlook on Agriculture, 31(1), 23-33.

JANAIAH, A. \& XIE, F. 2010. Hybrid rice adoption in India: farm level impacts and challenges. Technical Bulletin, (14), 1-20.

JEGEDE, O. C., BOLORUNDURO, P. I. \& IKANI, E. I. 2007. Levels of awareness and adoption of disseminated livestock technologies in Enugu state, Nigeria. Journal of Food, Agriculture and Environment, 5(2), 185-188.

LUCAS, M. \& PABUAYON, I. 2011. Risk Perceptions, Attitudes, and Influential Factors of Rainfed Lowland Rice Farmers in Ilocos Norte, Philippines. Asian Journal of Agriculture and Development, 8(2), 61-77.

NIRMALA, B. \& SUHASINI, K. 2013. Farmer's experience with hybrid rice technology : A case study of Khunti district of Jharkhand State of India. African Journal of Agricultural Research, 8(29), 3973-3975. doi:10.5897/AJAR12.662

NIRMALA, B., VASUDEV, N. \& SUHASINI, K. 2013. Farmer's Perceptions on Hybrid Rice Technology : A Case Study of Jharkhand. Indian Research Journal of Extension Education, 13(3), 103-105.

SANTIAGUEL, A. F. \& QUIPOT, L. M. 2012. Hybrids Head for the Tropics. Rice Today, $11(3), 40-41$.

SHAH, M. M. I., GRANT, W. J. \& STOCKLMAYER, S. 2014, 'Adoption of hybrid rice in Bangladesh: farm level experience. Journal of Agricultural Science, 6 (7), 157-171.

SINGH, A. K., KUMAR, B., BAGHEL, R. S. \& SINGH, R. B. 2009. Sustainability of Hybrid Rice Technology vis a vis Inbred Rice in Uttar Pradesh. Indian Res. J Ext. Edu., 9(2), 22-25. 
S.Afr. Tydskr. Landbouvoorl./S. Afr. J. Agric. Ext.,

Vol. 43, No. 2, 2015: $17-29$

DOI: http://dx.doi.org/10.17159/2413-3221/2015/v43n2a338

YUAN, L. 2012. Q \& A with the Father of Hybrid Rice. Rice Today, 11(3), 42-43.
Shah, Grant

\& Stocklmayer

(Copyright) 